ROCZNIKI TEOLOGICZNE

Tom LXVI, zeszyt 11 - 2019

DOI: http://dx.doi.org/10.18290/rt.2019.66.11-5

KS. KRZYSZTOF MIELNICKI

\title{
SZANSE I WYZWANIA WYCHOWANIA DO WARTOŚCI W EDUKACJI DOMOWEJ*
}

\author{
CHANCES AND CHALLENGES OF EDUCATION TOWARDS VALUES \\ IN HOME EDUCATION
}

\begin{abstract}
A b s t r a c t. The essence of education is to show what is valuable, and the message of educational environment should be common, clear and consistent. For shaping student's personality properly, such message should flown from the first basic, natural educational environment which is in the family home, and is created mainly by parents, but siblings and other relatives also contribute to creating it. Upbringing should be related to a paragon. Such a paragon gives human values, and even more Christian values accepting laws of nature which illuminate the Revelation of God. Home education creates favourable conditions to let integral development of a person take place based on values related to home. It gives a great opportunity, but it is also a challenge not only for those interested in such a form of family education but also for the society and the state.
\end{abstract}

Key words: home education; values; Christian values; family.

Budowanie społeczeństwa i gospodarki opartej na wiedzy, to jeden z ważniejszych priorytetów rozwijających się społeczeństw. Kluczem do jego realizacji jest dobrze zaplanowana i zorganizowana edukacja na wszystkich poziomach. Takie podejście do edukacji może akcentować bardziej kształcenie, niż

Ks. dr KRZYSZTOF MiELNICKI - Papieski Wydział Teologiczny w Warszawie Collegium Joanneum, nauki teologiczne w zakresie katechetyki; adres do korespondencji - e-mail: kmiel nicki03@gmail.com

* K. Mielnicki, Szanse i wyzwania wychowania do wartości w edukacji domowej, w: J. BielecKA-Prus (red.), Rodzina w edukacji domowej, Warszawa 2018, s. 102-115. 
wychowanie $^{1}$. Na pomniejszenie roli wychowania w dzisiejszej rzeczywistości ma również duży wpływ wszechobecna filozofia i pedagogika postmodernistyczna, według której wartości i wychowanie do nich określa się jako coś wielce subiektywnego i relatywnego, podlegającego osobistym preferencjom ${ }^{2}$. Podejmując temat edukacji, należy również zauważyć i to, że stosunkowo częste zmiany w polityce oświatowej państwa wprowadzają dezorientację, a nawet chaos w środowiskach wychowawczych. Trzeba też podkreślić, że na przestrzeni ostatnich dekad polityka oświatowa państwa i przyjęty przez państwo model wychowania nie zawsze służyły rodzinie i nie były zgodne z przekonaniami i wartościami uznawanymi przez rodziców. Powyższe przesłanki moga podpowiadać świadomym, odpowiedzialnym za wychowanie i wykształcenie swojego potomstwa, mającym do tego niezbywalne prawo rodzicom, że cały proces edukacji należy „wziąć w swoje ręce” i skorzystać $\mathrm{z}$ edukacji domowej ${ }^{3}$. Czy jednak edukacja domowa sprawdza się dzisiaj i jakie są jej założenia dotyczące wychowania do wartości, jakie ma ona szanse na rozwój i jakie stoją przed nią wyzwania? Na te i wynikające z nich pytania zamierza podjąć próbę odpowiedzi niniejszy artykuł.

\section{WYCHOWANIE DO WARTOŚCI}

Według definicji W. Okonia, wychowanie to „Świadomie organizowana działalność społeczna, której celem jest wywoływanie zamierzonych zmian w osobowości człowieka. Zmiany te obejmują zarówno stronę poznawczo-instrumentalną, związaną z poznaniem rzeczywistości i umiejętnością oddziaływania na nią, jak i kształtowania stosunku człowieka do świata i ludzi, jego przekonań i postaw, układu wartości i celu życia"4. Ilekroć mówimy o wychowaniu, tylekroć mówimy o wychowaniu do wartości. Dzieje się tak nawet wtedy, gdy tego nie artykułujemy, ponieważ całokształt wpływów wychowawcy na wychowanka, mający na celu wprowadzenie zmian w osobowości wy-

\footnotetext{
${ }^{1}$ Por. W. CELlaRY, Społeczeństwo informacyjne, czy społeczeństwo wiedzy?, https://www. edunews.pl/badania-i-debaty/opinie/313-spoleczenstwo-informacyjne-czy-spoleczenstwo-wiedzy [26.01.2018].

${ }^{2}$ Zob. M. STRĘBSKA-KOZIEE, O potrzebie wychowania do wartości, http://www.psychol ogia.net.pl/artykul.php?level=752 [25.01.2018].

${ }^{3}$ Zob. M. GŁowACKA, Edukacja domowa a przemiany nowoczesności, „Zoon Politikon” 2015, nr 6, s. 227-228.

${ }^{4}$ W. OKоŃ, Stownik Pedagogiczny, Warszawa 2001, s. 445.
} 
chowanka, zawsze opiera się na konkretnych wartościach, a wychowanie to główny przekaźnik wartości ${ }^{5}$. Chodzi w nim głównie o przygotowanie i doprowadzenie wychowanka do: uwewnętrznienia, dobrowolnego uznania za własne i realizowania w życiu wartości uważanych jako pożądane wychowawczo. Dokonuje się to na kilku etapach, a są to: odkrywanie, przeżywanie, interioryzacja i internalizacja wartości ${ }^{6}$.

Powszechnie używana definicja mówi o tym, że wartością jest „to wszystko, co uchodzi za ważne i cenne dla jednostki i społeczeństwa oraz jest godne pożądania, co łączy się z pozytywnymi przeżyciami i stanowi jednocześnie cel dążeń ludzkich"”. Błąd, jaki może się wkraść, to utożsamienie wartości z potrzebami. Potrzeby związane są z naturą człowieka, która w sytuacji jakiegoś braku popycha go do działania by zlikwidować ten brak $^{8}$. Natomiast wartości istnieją niezależnie od człowieka, a rola człowieka polega na ich poznawaniu ${ }^{9}$. Wartość może być celem i wówczas jest wartością wyższą, lub środkiem do celu i będzie to wartość niższa, ale zawsze będzie obiektywnym dobrem. Proces odkrywania wartości lub ich nadawania nazywamy wartościowaniem i czy tego chcemy czy nie, ciągle wartościujemy bardziej lub mniej świadomie, bo jest to jeden $\mathrm{z}$ wymiarów człowieczeństwa ${ }^{10}$.

Na pytanie: czy jest potrzeba wychowania do wartości, odpowiedzi udziela psychologia rozwojowa, która podejmuje próbę wyjaśnienia rozwoju sądów ewaluacyjnych opisując rozwój osoby, biorąc pod uwagę sferę moralną. Moralność przedkonwencjonalna, konwencjonalna i postkonwencjonalna z poszczególnymi stadiami, to trzy zasadnicze poziomy rozwoju moralnego ${ }^{11}$. Odpowiadaja one trzem fazom powstawania standardów sądów ewaluacyjnych: hedonistycznych, konformistycznych i poznawczych. W fazie sądów hedonistycznych: pozytywne

\footnotetext{
5 Zob. A. BINDEK, Wychowanie do wartości, http://studylibpl.com/doc/968058/wycho wanie-do-warto\%C5\%9Bci [31.01.2018].

${ }^{6}$ Zob. K. OLBRYCHT, Wychowanie do wartości - w centrum aksjologicznych dylematów wspótczesnej edukacji, „Pedagogia Christiana” 1/29(2012), s. 97.

${ }^{7}$ M. ŁobockI, Pedagogika wobec wartości, w: B. ŚLIWERSKI (red.), Kontestacje pedagogiczne, Kraków 1993, s. 125.

${ }^{8}$ Zob. A. NAGrodZKA, Potrzeby psychiczne dziecka, http://www.sp27.lublin.eu/wp-content /uploads/art/Potrzeby\%20psychiczne\%20dziecka.pdf [31.01.2018].

${ }^{9}$ Zob. L. ZARZECKI, Teoretyczne podstawy wychowania. Teoria i praktyka $w$ zarysie, Jelenia Góra 2012, s. 61.

${ }^{10}$ Zob. E. SOZAŃSKA, Rodzina jako środowisko wychowania w wartościach, „Łódzkie Studia Teologiczne" 32(2014), nr 3, s. 45.

${ }^{11}$ Por. H. KRETEK, Teorie i stadia rozwoju moralnego dzieci i młodzieży, „Nauczyciel i Szkoła" 1(51)2012, s. 64.
} 
jest to, co kojarzy się z przyjemnością, a negatywne to, co z przykrością. W fazie sądów konformistycznych pozytywne jest to, co jest aprobowane przez ważne osoby $\mathrm{z}$ otoczenia, a negatywne to, co uważane jest przez te osoby za złe. Faza sądów poznawczych polega na samodzielnym uznawaniu, według własnej oceny tego, co pozytywne lub negatywne. Nie ma w rozwoju człowieka takiego etapu, w którym nie zachodziłoby wartościowanie. Od pierwszych chwil po narodzeniu w dziecku kształtują się standardy ewaluacyjne. Najpierw jest to nieuświadamiane dążenie do nagrody przez naśladowanie i empatię, później coraz bardziej świadome dążenie do spełnienia oczekiwań innych, aż po wypracowanie własnych, autonomicznych opinii i sądów ${ }^{12}$.

Największy wpływ na ten proces ma dom rodzinny - rodzice, rodzeństwo i rodzina. Ważne jest, aby przekaz, płynący od najbliższego otoczenia dziecka, był na tyle jasny i klarowny, aby dostarczał zrozumiałych kryteriów oraz pokazywał konsekwentne reakcje i zachowania wobec konkretnych wartości. Temu procesowi powinno towarzyszyć cierpliwe wyjaśnianie zasad z tworzeniem przestrzeni do coraz bardziej samodzielnego wartościowania. Dla kompletności rozważań należy w tym miejscu dodać, iż na jakość funkcjonowania jednostki wpływają trzy czynniki: biologiczny, społeczny i aktywność własna, a aktywność własna jest, mniej lub bardziej świadomą, konsekwencją czynników biologicznego i społecznego ${ }^{13}$. Teorie mówiące o tym, że wychowywanie człowieka do wartości jest ograniczaniem jego wolności, w świetle powyższych stwierdzeń tracą rację bytu. Rezygnacja ze świadomej formacji w zakresie wydawania sądów wartościujących prowadzi nieuchronnie do tego, że ten proces dokonuje się w sposób przypadkowy. W takiej sytuacji duży wpływ na kształt tworzącego się systemu wartości będą miały osoby z różnymi systemami wartości, ale też przygodne zdarzenia, sytuacje i całe otoczenie. Takie osoby będą bardziej podatne na zaplanowane działania podmiotów zainteresowanych społecznym wpływem, a nawet manipulacją. Zaniedbania w sferze wychowania do wartości, przez zmienność kryteriów, brak zasad, konsekwencji i sprzeczne komunikaty, mogą sprawić, że rozwój osoby nie będzie przebiegał właściwie w kierunku dojrzałych zachowań, tylko zatrzyma się na etapie zachowań hedonistycznych i konformistycznych ${ }^{14}$.

\footnotetext{
${ }^{12} \mathrm{~K}$. OLBRYCHT, Wychowanie do wartości, http://www.fidesetratio.org.pl/files/plikipdf/ol brycht1.pdf [31.01.2018].

13 Por. J. Strelau, A. Jurkowski, Z. Putkiewicz (red.), Podstawy psychologii dla nauczycieli, Warszawa 1976, s. 53-83.

${ }^{14}$ Por. K. OlBRYCht, Dlaczego boimy się wartości w wychowaniu?, „Edukacja i Dialog” 2000, nr 2, s. 26-32.
} 


\section{WYCHOWANIE DO WARTOŚCI OPARTE NA DOMU}

Realizowany obecnie w Polsce model edukacji domowej został przeszczepiony z krajów anglojęzycznych i jest zorganizowany na ich wzór. Samo określenie ,edukacja domowa” jest tłumaczeniem terminów: Homeschooling, albo home education ${ }^{15}$. Takie określenie tej formy edukacji akcentuje uczenie w domu na wzór edukacji szkolnej. Każdy, kto miał możliwość nawet pobieżnego poznania od praktycznej strony tego sposobu nauczania i wychowania, zgodzi się, że lepiej oddaje istotę tego zjawiska inne angielskie określenie: home-based-education - edukacja oparta na domu ${ }^{16}$. To określenie zmienia kierunek myślenia z miejsca, gdzie realizuje się edukacja, w kierunku wartości na jakiej opiera się cały jej proces, jaką jest dom $\mathrm{z}$ całym bogactwem swego znaczenia ${ }^{17}$.

Definicja edukacji domowej mówi, że jest to „nauczanie dzieci oraz młodzieży przez ich rodziców lub guwernerów, odbywające się w miejscu zamieszkania poza systemem szkolnym (w Polsce związanym z Ministerstwem Edukacji Narodowej. Edukacja domowa, jako niesformalizowany biurokratycznie rodzaj opieki i wychowania indywidualnego dziecka w gronie rodzinnym, odbywa się od wieków przez całe życie człowieka jako istoty społecznej)" ${ }^{\prime 18}$. Fundamentalna teza, która stanowi podwaliny edukacji opartej na domu jest taka, że wychowanie to dar przekazywany przez rodziców dzieciom przez pokolenia w rodzinie. Rodzice są naturalnymi wychowawcami odpowiadającymi za przygotowanie do życia swoich dzieci. To, co mogą i powinny zrobić inne środowiska wychowawcze, a głównie państwo, ale też Kościół i media, to uznanie praw rodziców do wychowania dzieci i wsparcie ich przez pomoc przede wszystkim we wzmocnieniu więzi rodzinnych ${ }^{19}$.

Sięgając do historii naszego kraju należy stwierdzić, że rodzina polska na przestrzeni wieków była środowiskiem kształtującym młode pokolenia, które potrafiły przekazać wartości, które pomogły narodowi polskiemu przetrwać

\footnotetext{
${ }^{15}$ A. KuCharsKa, Dlaczego edukacja domowa? Aksjologiczne uzasadnienia edukacji bez. szkoty, „Wychowanie w Rodzinie” 10(2014), nr 2, s. 207.

${ }^{16}$ M. BudajCZaK, Edukacja domowa, Gdańsk 2004, s. 19.

${ }^{17}$ Por. D. SzCZYGIELSKI, Matżeństwo i rodzina jako wartość w świadomości młodzieży na podstawie wyników badań socjologicznych $w$ katolickich liceach ogólnokształcacych w Szczecinie, w: Teoretyczny i praktyczny wymiar sprawności moralnych w wychowaniu, red. I. Jazukiewicz, Szczecin 2015, s. 249.

18 https://pl.wikipedia.org/wiki/Edukacja_domowa [29.01.2018].

${ }^{19}$ Zob. M. BUdAJCZAK, Edukacja domowa, s. 32-34.
} 
i zachować swoją tożsamość ${ }^{20}$. Nauczanie domowe funkcjonowało od czasów Rzeczypospolitej szlacheckiej nieraz równolegle z oświatą powszechną, choć $\mathrm{w}$ różnym zakresie i zasięgu ${ }^{21}$. Wiele światła na to zagadnienie rzucają opracowania, w których jest mowa o edukacji domowej magnaterii ${ }^{22}$, ziemiaństwa ${ }^{23}$, dzieci z rodzin mieszczańskich i wiejskich, a także tajnym nauczaniu prowadzonym $w$ domach $w$ czasie zaborów ${ }^{24}$. Stosunkowo największą wiedzę posiadamy na temat tajnego nauczania w czasie okupacji hitlerowskiej $^{25}$, a znacznie mniejsza jest ta dotycząca okupacji radzieckiej ${ }^{26}$. Nie mniej jednak zjawisko nauczania domowego na przestrzeni ostatnich stuleci dotyczyło wszystkich sfer społecznych i kształtowane było przez wiele czynników, a wartości, na których było ono oparte, to dom i rodzina ${ }^{27}$.

Po zmianach ustrojowych w Polsce edukację domową usankcjonowała i uregulowała ustawa o systemie oświaty z 7 września 1991 roku, która obecnie, po reformie oświaty, ma kształt Ustawy o prawie oświatowym z 14 grudnia 2016 roku. W myśl tego dokumentu możliwe jest uczenie się dzieci poza szkołą, w domu rodzinnym w warunkach zorganizowanych przez rodziców. Ustawa reguluje to, o czym mówi Konstytucja Rzeczypospolitej Polskiej, która gwarantuje rodzicom prawo do wychowywania i kształcenia dzieci w szkołach innych niż publiczne, zgodnie z własnymi przekonaniami, z uwzględnieniem dojrzałości dziecka, poszanowaniem wolności jego sumienia i wyznania ${ }^{28}$. Bezdyskusyjne pierwszeństwo rodziców potwierdzają rów-

\footnotetext{
${ }^{20}$ Por. A. ZIELIŃSKI, Poczatek wieku. Przemiany kultury narodowej w latach 1807-1831, Łódź 1973.

${ }^{21}$ Por. K. JAKUBIAK, A. WinIARZ (red.), Nauczanie domowe dzieci polskich od XVIII do XX wieku. Zbiór studiów, Bydgoszcz 2004.

${ }^{22}$ Por. K. ADAmCZYK, Do wychowania synów moich. Uwagi generała Władystawa Zamoyskiego, w: Rodzina jako środowisko wychowawcze w czasach nowożytnych, red. K. Jakubiak, Bydgoszcz 1995, s. 81-85.

${ }^{23}$ Por. T. EPSTEIN, Edukacja domowa dzieci i młodzieży ziemiańskiej na Wotyniu, Podolu i Ukrainie w latach 1864-1914, w: Wychowanie w rodzinie od starożytności po wiek XX, red. J. Jundziłł, Bydgoszcz 1994, s. 333-346.

${ }^{24}$ Por. B. NAWROCZYŃSKI (red.), Nasza walka o szkołe polska 1901-1917. Opracowanie, wspomnienia, dokumenty, Warszawa 1932, t. I; 1934, t. II.

25 Por. J. KRASUSKI, Oświata i szkolnictwo w okresie okupacji (1939-1945). w: Historia wychowania wiek XX, t. 1, red. J. Miąso, Warszawa 1980.

${ }^{26}$ Por. A. SudOŁ (red.), Sowietyzacja Kresów Wschodnich II Rzeczypospolitej po 17 września 1939 r., Bydgoszcz 1998.

${ }^{27}$ Por. M. NAWROT-BorowsKa, Nauczanie domowe na ziemiach polskich $w$ drugiej połowie XIX i poczatkach XX wieku - zapatrywania teoretyczne i praktyka, Bydgoszcz 2011.

${ }^{28}$ Konstytucja Rzeczypospolitej Polskiej Art. 48 ust. 1, Art. 53 ust. 3, Art. 70 ust. 3,
} 
nież międzynarodowe dokumenty podpisane przez Polskę: Powszechna Deklaracja Praw Człowieka ${ }^{29}$ i Konwencja o Prawach Dziecka ${ }^{30}$.

Motorem podjęcia przez rodziców decyzji o tym, że swoje prawa i obowiązki dotyczące opieki i wychowania dzieci będą realizować korzystając z edukacji domowej, najczęściej jest sfera wartości. Chodzi o wychowanie i nauczanie nastawione na wartości i spójny obraz świata, wynikający z przekonań rodziny. $\mathrm{W}$ procesie edukacji nie chodzi tylko o zdobycie wiedzy albo sprawności, ale głównie o to w jaki sposób myślimy o sobie i otaczającym nas świecie, jak odnajdujemy się w rodzinie i społeczeństwie, o poczucie bycia kimś. Ponadto przekazywanie wiedzy nie jest neutralne światopoglądowo. Rozbieżności pomiędzy systemem prawd głoszonych przez rodzinę a tym, który jest głoszony w szkole sprawia, że rodzice, zajmujący się dzieckiem od początku jego życia, nie chcą zlecać tej ważnej sprawy instytucji i nieznanym osobom. Postanawiają ten obowiązek wziąć na siebie. Daje to dużą szansę na powodzenie, aby trwał pokoleniowy przekaz wartości i na ich kanwie była kształtowana moralność na wszystkich etapach rozwojowych ${ }^{31}$.

Sami rodzice, pytani o najważniejszą wartość w całym procesie edukacyjnym, wskazują rodzinę. Ponadto, edukacja domowa opiera się na takich wartościach, jak: życie, szacunek dla innych, odpowiedzialność, sprawiedliwość, odwaga, pracowitość, uczciwość, tradycja, patriotyzm, wiara, dobro dziecka, indywidualny rozwój dziecka i jakość kształcenia, elastyczność i niezależność. Prowadzeniem edukacji domowej najczęściej zajmują się matki dzieci rezygnując z pracy zawodowej na rzecz prowadzenia domu. Ojcowie jako ci, którzy są żywicielami rodziny, mniej czasu poświęcają dzieciom, ale przez to, że dzieci edukują się w domu, mają możliwość kontaktu z nimi i wykorzystywania wolnego czasu na budowanie więzi przez zabawę czy naukę, inwestując w ich duchowy rozwój. Bywa i tak, że rodziny współpracują ze sobą wymieniając się obowiązkami, tworząc możliwości budowania naturalnych relacji społecznych z osobami w różnym wieku z otoczenia rodziców, ewentualnie proszą o wsparcie nauczycieli z konkretnych dziedzin - o pomoc w nauce dziecka. To wszystko jest zgodne z koncepcją wiodącej roli rodzi-

\footnotetext{
http://www.sejm.gov.pl/prawo/konst/polski/kon1.htm [31.01.2018].

${ }^{29} \mathrm{http} / / /$ libr.sejm.gov.pl/tek01/txt/onz/1948.html [31.01.2018].

${ }^{30} \mathrm{http}$ ://prawo.sejm.gov.pl/isap.nsf/DocDetails.xsp?id=WDU19911200526 [31.01.2018].

${ }^{31}$ Por. K. WenKLAR, Edukacja domowa - pięć najczęściej stawianych pytań, „Edukacja Elementarna w Teorii i Praktyce" 30(2013), nr 4, s. 112.
} 
ców, którzy decydują o tym, jak ma wyglądać edukacja ich dzieci, z kim spędzają czas i co w tym czasie robią ${ }^{32}$.

Świadomość celu wychowania i tego, że w osiągnięciu celu przeszkadza bałagan, brak planowania, niespójność wymagań, a pomagaja przemyślane i uzasadnione kroki podejmowane wobec wychowanka, jest jednym z pierwszych etapów odpowiedzialnego wychowania do wartości w każdej edukacji, a szczególnie tej, która jest oparta na domu. Wychowanie powinno zmierzać do integralnego rozwoju osoby do pełni człowieczeństwa, aby tak było, powinno mieć odniesienie do solidnego wzorca. Taki wzorzec dają wartości ogólnoludzkie, a w jeszcze większym stopniu wartości chrześcijańskie, akceptujące prawa natury, które rozświetla Objawienie Boże ${ }^{33}$. Rodzice powinni zastanowić się, które wartości są - według nich - najważniejsze: materialne czy duchowe, ogólnoludzkie czy wartości chrześcijańskie i co jest dla nich największą wartością ${ }^{34}$. Niektóre wartości na przestrzeni lat, na skutek przemian kulturowych, zostały zmarginalizowane, inne są coraz bardziej eksponowane, a są i takie, które powstają na naszych oczach. Które powinny być bardziej akcentowane w przekazie, czy podstawowe, np. wiara, dobro wspólne, sprawiedliwość, czy patriotyzm, czy samorealizacyjne, które są związane z rozwojem jednostki? To są pytania, na które powinni odpowiedzieć rodzice świadomie wychowujący swoje dzieci do wartości ${ }^{35}$.

Kluczowym zadaniem, jakie stoi przed dobrymi wychowawcami, jest budowanie, wzmacnianie i pielęgnacja właściwych relacji w rodzinie $\mathrm{w}$ oparciu o wartości, które w dorosłym życiu będą owocowały pozytywnymi zachowaniami i postawami prospołecznymi. Dziecko nie ma zakodowanych zachowań, uczy się wzorców zachowań od rodziców przez naśladowanie. Rodzice tłumaczą dziecku co jest dobre, a co złe i dlaczego. Dziecko słucha, obserwuje reakcje i zachowania rodziców i przejmuje od niech hierarchię wartości. Modyfikuje ją kierując się przede wszystkim tym, jak postępują rodzice i inni z ich otoczenia. Dlatego przekaz rodziców, najważniejszych wychowawców,

\footnotetext{
32 Por. A. KUCharsKa, Dlaczego edukacja domowa?, s. 214-221.

${ }^{33}$ Por. W. DYK, Wartości chrześcijańskie podstawa wychowania w szkole europejskiej, w: Wychowanie moralne w szkole katolickiej, red. A.J. Sowiński, A. Dymer, Szczecin 2003, s. 231-241.

${ }^{34}$ Zob. B. WoŁosıuk, Wartości chrześcijańskie w wychowaniu dzieci w młodszym wieku szkolnym, „Paedagogia Christiana” 1/27(2011), s. 185-202.

35 Zob. G. Pighin, Jak przekazywać dzieciom wartości, Kraków 2006, s. 25-26. Por. Z. KlimCZuK, Podstawowe zasady życia spotecznego, „Studia Warmińskie” 44-45(2007-2008), s. $156-158$.
} 
powinien być spójny w słowach i czynach. Rodzice ukrywając przed dzieckiem swoje problemy, bagatelizując, nie wyjaśniając na tyle, na ile wystarczy dziecku wiedzieć, odsyłając je w sytuacji kiedy pyta ono, co się dzieje, do zabawek albo kolegów, tworzą w dziecku mechanizm, który nie uczy ani szczerości, ani empatii. W przyszłości tak utrwalone rozwiązanie będzie mogło owocować takim podejściem, jak będzie działa się komuś krzywda, że to nie jego sprawa, a on będzie mógł ze spokojem zająć się czymś, co jest dla niego przyjemne. Rodzice w wychowaniu do wartości przekażą hierarchię wartości, jeśli sami będą według niej żyli. Powinni mieć zrozumiałe reguły i zasady postępowania, dawać pozytywne wzorce zachowań i postaw. Atmosfera domu, w którym panuje miłość, wzajemna otwartość i dialog, jest nie do przecenienia i nie ma żadnej alternatywny równej sobie w postaci szkoły czy innego środowiska wychowawczego ${ }^{36}$.

\section{SZANSE I WYZWANIA}

Wiele miejsca poświęca się na wskazanie plusów i minusów edukacji domowej, i tak też możemy ująć wychowanie do wartości. Jednak każdy plus można zrównoważyć jakimś minusem i na odwrót. Może okazać się bardziej twórczym, więcej wnoszącym do rozważań, wskazanie pewnych istotnych elementów dla edukacji domowej, rozpatrywanych w perspektywie szans i wyzwań stojących przed wychowaniem do wartości ${ }^{37}$.

\section{Dom, rodzice, rodzeństwo i rodzina}

To wielka szansa na integralne wychowanie w duchu wartości wyznawanych przez rodzinę, przekazywanych z pokolenia na pokolenie. Dzieci, uczące się w domu, uczą się wartości, które przekazują im ich rodzice najbardziej przez naśladowanie. To też wyzwanie dla rodziców, by ich przekaz był kla-

\footnotetext{
${ }^{36}$ Zob. T. RostowsKa, System wartości rodziców i dzieci jako zadanie rozwojowe, w: Rodzina: źródto życia i szkoła miłości, red. D. Biela, Lublin 2001, s. 219; por. G. PIGHIN, Jak przekazywać dzieciom wartości, Kraków 2006, s. 25-26.

${ }^{37}$ Zob. A. CZAJKowsKA, Zalety $i$ wady edukacji domowej, https://www.dziecirosna.pl /szko la/szkola_podstawowa/zalety_i_wady_edukacji_domowej.html [31.01.2018]; M. OsZCZEPALIŃSKA, Czy taka forma ksztatcenia dziecka będzie idealna?, http://polki.pl/rodzina/dziecko,zalety-i-wadyedukacji-domowej,10416169, artykul.html [31.01.2018]; A. BUJAS, Edukacja domowa (homeschooling) - zasady, zalety $i$ wady nauczania domowego..., http://www.biomedical. pl/dziecko/edukacjadomowa-homeschooling-6513.html [31.01.2108]; M. PRZYPŁATA, Wady i zalety edukacji domowej, http://www.smykgroup.com/pl/wady-i-zalety-edukacji-domowej/ [31.01.2018].
} 
rowny i wspólny. To z kolei wymaga od rodziców swego rodzaju pracy nad sobą w takim porządkowaniu świata wartości, w którym będzie jasna hierarchia wartości z uwzględnieniem wartości podstawowych, jako pierwszych przed osobowymi i samorealizacyjnymi ${ }^{38}$. W tym aspekcie dużą pomocą rodzinie może okazać się chrześcijański system wartości, który jest podstawowym stymulatorem rozwoju ludzkości na wielu płaszczyznach ${ }^{39}$.

\section{Wychowanie}

Gdy życie rodziny podporządkowane jest wychowaniu, szansą jest to, że w edukacji domowej jest dużo czasu na bycie ze sobą, na budowanie relacji przez wspólną zabawę, naukę i pracę, w atmosferze wzajemnego zaufania. Wyzwanie z tym związane polega na tym, że rodzice, spędzając czas z dziećmi, powinni zwracać uwagę na wspólne działanie, by było radosne, twórcze, ciekawe, by uczyło dzieci i rozwijało ich pasje i zainteresowania, by kształtowało dojrzałe zachowania i postawy. Równie ważną sprawą jest i ta, że zmęczenie, błędy i porażki wychowawcze mogą uniemożliwić rodzicom dalszą edukację, dlatego ważne jest by rodzice, kształcący dziecko w domu, dbali o swoje potrzeby, o rozwój swoich zainteresowań i pasji, by czuli się spełnieni jako osoby ${ }^{40}$.

\section{Nauczanie}

W edukacji domowej klasą lekcyjną jest cały otaczający świat, z nieskończoną ilością pomocy naukowych. Szansą jest łatwość w zdobywaniu wiedzy w sposób spontaniczny i naturalny przez obserwację i eksperyment, ale też przy wykorzystaniu możliwości telewizji i Internetu z dużą ilością kanałów, programów i stron popularnonaukowych, albo wprost edukacyjnych. Rodzic nie musi być wykształconym pod każdym względem nauczycielem. Wyzwaniem w tym aspekcie będzie twórcze, ale i odpowiedzialne podejście rodziców do roli nauczyciela i zadań z nią związanych. Proces nauczania i uczenia pomimo swej spontaniczności i elastyczności powinien być oparty na konkretnym planie nauczania, realizowany systematycznie i w pewnej dyscyplinie, by przygotowywał dzieci do egzaminów klasyfikacyjnych. W razie trudności w przekazie wiedzy z konkretnych przedmiotów mogą zwrócić się z prośbą o pomoc do innych rodzin $\mathrm{z}$ nauczania domowego, nawiązać kontakt przez

\footnotetext{
${ }^{38}$ Por. L. SZYMCZYK, Dziecko w kręgu wartości rodzinnych, „Nauczyciel i Szkoła” 2009, nr 3-4 (44-45), s. 43-52.

39 Por. M. TAlARCZYK, Znaczenie wartości, „Wychowawca” 6(2004), s. 8-10.

${ }^{40}$ Por. K. ChaŁAs, Wychowanie ku wartościom. Elementy teorii i praktyki, t. 1, Kielce 2003, s. 16 .
} 
szkołę zajmującą się edukacją domową, z nauczycielami prowadzącymi konsultacje lub zatrudnić korepetytora. Innym wyzwaniem z tym związanym jest pogodzenie obowiązków domowych z potrzebami edukacyjnymi dziecka ${ }^{41}$.

\section{Indywidualizacja}

Wielką szansą dla rozwoju dziecka w edukacji domowej jest spersonalizowanie wysiłków edukacyjnych, uwzględniając jego potencjał i koncentracja na dziecku. Znając możliwości intelektualne i fizyczne, bądź też różnego rodzaju ograniczenia dziecka, można w taki sposób je prowadzić, aby optymalnie rozwijało się jako osoba, nie pomijając jego zainteresowań. Wyzwanie dla rodziców w tym aspekcie jest takie, że powinni oni tworzyć atmosferę zaufania i akceptacji, dając dziecku wsparcie psychiczne oraz dokonywać analizy obserwowanych postępów dziecka by dostosowywać do nich tempo - zwiększać dla zdolnych i zmniejszać dla słabszych, treści i metody pracy ${ }^{42}$.

\section{Kształcenie permanentne}

Nauka w edukacji domowej nigdy się nie kończy, ta teza wpisuje się w przekonanie panujące w dzisiejszym świecie, mówiące o tym, że przy takim dużym tempie przemian musimy być w stanie edukacji permanentnej. To wielka szansa na ciągły rozwój człowieka, a jednocześnie wyzwanie dla rodziców, by organizowali edukację w taki sposób, aby dzieci uczyły się czegoś bez przerwy, żyjąc przy tym prawdziwym życiem, w dopasowaniu do zainteresowań i zdolności dzieci, kształtując postawę otwartości na ciągły rozwój ${ }^{43}$.

\section{Socjalizacja}

Sposób na socjalizację przez kontakt z różnymi osobami. Dzieci w edukacji domowej spędzają dużo czasu z osobami w różnym wieku, co jest szansą na socjalizację, może o wiele lepszą od tej szkolnej, gdzie uczniowie podzieleni są na grupy wiekowe, czyli na rzeczywistość, która jest nierealna w dorosłym życiu. Jest to też wyzwanie skierowane w kierunku rodziców, aby wykorzystywali każdą z możliwych sytuacji do tego, by uczyć dzieci procesu socjalizacji różnymi sposobami, przez kontakt $\mathrm{z}$ rodziną, $\mathrm{z}$ innymi rodzinami, ale i pojedynczymi osobami w różnym wieku i wykształceniu,

\footnotetext{
${ }^{41}$ M. BUdAJCZAK, Edukacja domowa, s. 92-99.

${ }^{42}$ Por. K. MARTYNA, Edukacja domowa w Polsce - szanse i zagrożenia, http://www.pp p1.wroc.pl/KMartyna_Edukacja_domowa_w_Polsce.pdf [31.01.2018].

${ }^{43}$ W. KoŁOdZIEJCZYK, M. POLAK, Jak będzie zmieniać się edukacja? Wyzwania dla polskiej szkoty i ucznia, Warszawa 2011, s. 66-67.
} 
takimi które będą miały pozytywny wpływ na rozwój dziecka. Ważną rolę spełniają również zajęcia dla dzieci, gdzie będą przebywały w grupie innych osób, np. zajęcia muzyczne, taneczne, sportowe. Wyzwaniem, stojącym przed rodzinami, jest kształtowanie zachowań i postaw prospołecznych ${ }^{44}$.

\section{Niezależność}

Edukacja domowa przez swoją formę oswaja z pewną niezależnością, w której nie ma ograniczeń miejsca, czasu dzwonków, zebrań, prac domowych i klasówek, nie ma pytań o możliwość np. zadania pytania, a w to miejsce jest spontaniczność i możliwość decydowania o sobie, bez przymusu zewnętrznego i bez ocen. Światopogląd i styl kształcenia, przyjęty przez rodziców, jeszcze bardziej mogą podkreślić niezależność osoby wyróżniającej się własnym zdaniem, sposobem myślenia i wyrażania swoich poglądów. To wielka szansa na rozwój dla samej zainteresowanej osoby, która funkcjonuje często poza schematami kształcenia i wychowania narzuconymi z zewnątrz. To również szansa dla społeczeństwa obywatelskiego, które dzięki takim osobom może mieć większy potencjał do samoorganizowania się i działania dla dobra ogółu. Jest również wyzwaniem dla rodziny, by wszystkie jej szeroko pojęte zabiegi edukacyjne służyły integralnemu rozwojowi osoby dziecka, które w odpowiedzialny i dojrzały sposób odnajdzie się w życiu prywatnym i społecznym. Jest to również wyzwanie, jakie stoi przed państwem, by polityka oświatowa tak była skonstruowana, by nie ograniczała rodziny $\mathrm{w}$ realizacji naturalnego prawa do wychowania zgodnie $\mathrm{z}$ własnymi przekonaniami i możliwościami dziecka, tylko mądrze ją wspierała, pamiętając o zasadach społecznych regulujących życie społeczne: pomocniczości, solidarności i dobra wspólnego ${ }^{45}$.

\section{Finansowanie}

Kosztami za edukację domową w obecnym jej kształcie w zasadniczej części obciążeni są rodzice, w mniejszej części szkoła, która zajmuje się uczniem w tym systemie. Jest to wyzwanie dla całej rodziny, bo takie ustawienie spraw wymaga obecności przynajmniej jednego rodzica w domu. To znaczy, że możliwości zarobkowania obojga rodziców z tego względu są ograniczone i rodzinę musi być stać materialnie, ale też psychicznie na taką formę edukacji. Bo nie musi to oznaczać, że jest ona zarezerwowana dla osób zamożnych. Taka sytuacja może być szansą dla rodziców, aby kreatywnie

\footnotetext{
44 Zob. M. BUDAJCZAK, Edukacja domowa, s. 55-65.

45 Por. Z. KLIMCZuK, Podstawowe zasady zycia społecznego, s. 163-170.
} 
spojrzeli na swoje możliwości zarobkowe, szukając różnych form pracy, biorąc pod uwagę sytuację rodzinną, czas pracy, jak i miejsce jej wykonywania. Jest również wyzwaniem dla państwa, które powinno pełnić rolę wspierającą rodzinę, by wsparcie w zakresie edukacji nie dotyczyło tylko instytucji, ale w przypadku nauczania domowego również rodzin. Mogło by to przybrać różne formy, np. współfinansowania z rodzicami projektów edukacyjnych, przygotowywanych przez konkretne rodziny na ich potrzeby ${ }^{46}$.

Edukacja oparta na domu, w której wiodącym elementem jest wychowanie w duchu wartości preferowanych przez rodziców i tradycje rodzinne, w której wszystko staje się okazją do nauczania i uczenia się z uwzględnieniem potrzeb i możliwości dziecka jest wielką szansą. Szansą na rozwój samej zainteresowanej osoby, jej rodziny, ale też i społeczeństwa oraz państwa. Otwartym pozostaje pytanie w jaki sposób pomagać wszystkim zainteresowanym osobom taką formą edukacji, i co zrobić by służyła ona jeszcze bardziej rodzinie i przyszłym pokoleniom. Dużą pomocą rodzinie może okazać się przyjęcie przez nią systemu wychowawczego opartego na wartościach ogólnoludzkich, a także chrześcijańskich. Pożądane są kampanie informacyjne na temat edukacji domowej, a także debaty społeczne na temat wartości wychowania opartego na domu, które miałyby na celu podkreślenie i wzmocnienie roli rodziny w procesie wychowania i nauczania młodego pokolenia.

\section{BIBLIOGRAFIA}

ADAMCZYK K., Do wychowania synów moich. Uwagi generała Władysława Zamoyskiego, w: Rodzina jako środowisko wychowawcze w czasach nowożytnych, red. K. Jakubiak, Bydgoszcz 1995.

BINDEK A., Wychowanie do wartości, http://studylibpl.com/doc/968058/wychowanie-do-warto \%C5\%9Bci [31.01.2018].

BUDAJCZAK M., Edukacja domowa, Gdańsk 2004.

BUJAS A., Edukacja domowa (homeschooling) - zasady, zalety i wady nauczania domowego..., http://www.biomedical.pl/dziecko/edukacja-domowa-homeschooling-6513.html[31.01.2108].

\footnotetext{
${ }^{46}$ Por. J. Helios, Edukacja domowa - kilka uwag w kontekście dyskursu o edukacji demokratycznej, „Filozofia Publiczna i Edukacja Demokratyczna” 3(2014), nr 2, s. 180-198.
} 
Cellary W., Społeczeństwo informacyjne, czy społeczeństwo wiedzy?, https://www.edunews. $\mathrm{pl} /$ badania-i-debaty/opinie/313-spoleczenstwo-informacyjne-czy-spoleczenstwo-wiedzy [26.01.2018].

ChaŁas K., Wychowanie ku wartościom. Elementy teorii i praktyki, t. 1, Kielce 2003.

CZAJKOWSKA A., Zalety i wady edukacji domowej, https://www.dziecirosna.pl/szkola/szkola_ podstawowa/zalety_i_wady_edukacji_domowej.html [31.01.2018].

DYK W., Wartości chrześcijańskie podstawą wychowania w szkole europejskiej, w: Wychowanie moralne w szkole katolickiej, red. A.J. Sowiński, A. Dymer, Szczecin 2003.

EPSTEIN T., Edukacja domowa dzieci i młodzieży ziemiańskiej na Wołyniu, Podolu i Ukrainie w latach 1864-1914, w: Wychowanie w rodzinie od starożytności po wiek XX, red. J. Jundziłł, Bydgoszcz 1994.

GŁowACKA M., Edukacja domowa a przemiany nowoczesności, „Zoon Politikon” 2015, nr 6.

Helios J., Edukacja domowa - kilka uwag w kontekście dyskursu o edukacji demokratycznej, „Filozofia Publiczna i Edukacja Demokratyczna” 3(2014), nr 2, s. 180-198.

JAKUBIAK K., A. WinIARZ (red.), Nauczanie domowe dzieci polskich od XVIII do XX wieku. Zbiór studiów, Bydgoszcz 2004

KLIMCZUK Z., Podstawowe zasady życia społecznego, „Studia Warmińskie” 44-45(2007-2008).

KoŁodzIeJczyK W., Polak M., Jak będzie zmieniać się edukacja? Wyzwania dla polskiej szkoły i ucznia, Warszawa 2011, s. 66-67.

KRASUSKI J., Oświata i szkolnictwo w okresie okupacji (1939-1945). w: Historia wychowania wiek XX, t. 1. red. J. Miąso, Warszawa 1980.

KRETEK H., Teorie i stadia rozwoju moralnego dzieci i młodzieży, „Nauczyciel i Szkoła” $1(51) 2012$.

KuChARSKA A., Dlaczego edukacja domowa? Aksjologiczne uzasadnienia edukacji bez szkoły, „Wychowanie w Rodzinie” 10(2014), nr 2.

ŁoвосKI A., Pedagogika wobec wartości, w: Kontestacje pedagogiczne, red. B. Śliwerski, Kraków 1993.

MARTYNA K., Edukacja domowa w Polsce - szanse i zagrożenia, http://www.ppp1.wroc.pl/ KMartyna_Edukacja_domowa_w_Polsce.pdf [31.01.2018].

MiElNICKI K., Szanse i wyzwania wychowania do wartości w edukacji domowej, w: Rodzina w edukacji domowej, red. J. Bielecka-Prus, Warszawa 2018.

NAgrodzKA A., Potrzeby psychiczne dziecka, w: http://www.sp27.lublin.eu/wp-content/uplo ads/art/Potrzeby\%20psychiczne\%20dziecka.pdf [31.01.2018].

NAWROCZYŃSKI B. (red.), Nasza walka o szkołę polską 1901-1917. Opracowanie, wspomnienia, dokumenty, Warszawa 1932, t. I; 1934, t. II.

NAWrot-BorowsKa M., Nauczanie domowe na ziemiach polskich w drugiej połowie XIX i początkach XX wieku - zapatrywania teoretyczne i praktyka, Bydgoszcz 2011.

OKOŃ W., Słownik Pedagogiczny, Warszawa 2001.

OLBRYCHT K., Dlaczego boimy się wartości w wychowaniu?, „Edukacja i Dialog” 2000, nr 2.

OLBRYCHT K., Wychowanie do wartości, http://www.fidesetratio.org.pl/files/plikipdf/olbrycht1. pdf [31.01.2018].

OLBRYCHT K., Wychowanie do wartości - w centrum aksjologicznych dylematów współczesnej edukacji, „Pedagogia Christiana” 1/29(2012).

OsZCZEPALIŃSKA M., Czy taka forma kształcenia dziecka będzie idealna?, http://polki.pl/rod zina/dziecko,zalety-i-wady-edukacji-domowej,10416169,artykul.html [31.01.2018].

PIGHIN G., Jak przekazywać dzieciom wartości, Kraków 2006.

PRZYPŁATA M., Wady i zalety edukacji domowej, http://www.smykgroup.com/pl/wady-i-zaletyedukacji-domowej/[31.01.2018]. 
RostowsKa T., System wartości rodziców i dzieci jako zadanie rozwojowe, w: Rodzina: źródło życia i szkoła miłości, red. D. Biela, Lublin 2001, s. 217-230.

SOZAŃSKA E., Rodzina jako środowisko wychowania w wartościach, „Łódzkie Studia Teologiczne" 32(2014), nr 3, s. 39-51.

STRĘBSKA-KOZIEŁ, O potrzebie wychowania do wartości, http://www.psychologia.net.pl/artykul. php?level=752 [25.01.2018].

Strelau J., Jurkowski A., Putkiewicz Z. (red.), Podstawy psychologii dla nauczycieli, Warszawa 1976

Sudo€ A. (red.), Sowietyzacja Kresów Wschodnich II Rzeczypospolitej po 17 września 1939 r., Bydgoszcz 1998.

SZCZYGIELSKI D., Małżeństwo i rodzina jako wartość w świadomości młodzieży - na podstawie wyników badań socjologicznych w katolickich liceach ogólnokształcących w Szczecinie, w: Teoretyczny i praktyczny wymiar sprawności moralnych w wychowaniu, red. I. Jazukiewicz, Szczecin 2015, s. 237-268.

SZYMCZYK L., Dziecko w kręgu wartości rodzinnych, „Nauczyciel i Szkoła” 2009, nr 3-4 (44-45).

TALARCZYK M., Znaczenie wartości, „Wychowawca” 6(2004), s. 8-10.

WENKLAR K., Edukacja domowa - pięć najczęściej stawianych pytań, „Edukacja Elementarna w Teorii i Praktyce" 30(2013), nr 4.

WoŁosıUK B., Wartości chrześcijańskie w wychowaniu dzieci w młodszym wieku szkolnym, „Paedagogia Christiana” 1/27(2011), s. 185-202.

ZARZECKI L., Teoretyczne podstawy wychowania. Teoria i praktyka w zarysie, Jelenia Góra 2012.

ZIELIŃSKI A., Początek wieku. Przemiany kultury narodowej w latach 1807-1831, Łódź 1973.

Edukacja domowa, https://pl.wikipedia.org/wiki/Edukacja_domowa [29.01.2018].

Konstytucja Rzeczypospolitej Polskiej Art. 48 ust. 1, Art. 53 ust. 3, Art. 70 ust.3, http://www. sejm.gov.pl/prawo/konst/polski/kon1.htm

Powszechna Deklaracja Praw Człowieka, http://libr.sejm.gov.pl/tek01/txt/onz/1948.html

Konwencja o Prawach Dziecka, http://prawo.sejm.gov.pl/isap.nsf/DocDetails.xsp?id=WDU 19911200526

\section{SZANSE I WYZWANIA WYCHOWANIA DO WARTOŚCI W EDUKACJI DOMOWEJ}

S t r e s z c z e n i e

Istotą wychowania jest ukazanie tego, co wartościowe, a przekaz środowiska wychowawczego na temat wartości powinien być wspólny, klarowny i konsekwentny. Dla prawidłowego ukształtowania osobowości wychowanka, taki przekaz powinien płynąć z pierwszego, podstawowego, naturalnego środowiska wychowawczego, które funkcjonuje w domu rodzinnym, a tworzą je przede wszystkim rodzice, ale też rodzeństwo i dalsza rodzina. Wychowanie powinno mieć odniesienie do solidnego wzorca. Taki wzorzec dają wartości ogólnoludzkie, a w jeszcze większym stopniu wartości chrześcijańskie, akceptujące prawa natury, które rozświetla Objawienie Boże. Dogodne warunki do tego, by mógł dokonywać się integralny rozwój osoby w oparciu o wartości związane z domem, stwarza edukacja domowa. Daje ona dużą szansę, ale jest również wyzwaniem dla zainteresowanych taką formą kształcenia rodzin, jak również społeczeństwa i państwa.

Słowa kluczowe: edukacja domowa; homeschooling; wychowanie; wartości; wartości chrześcijańskie; rodzina. 